
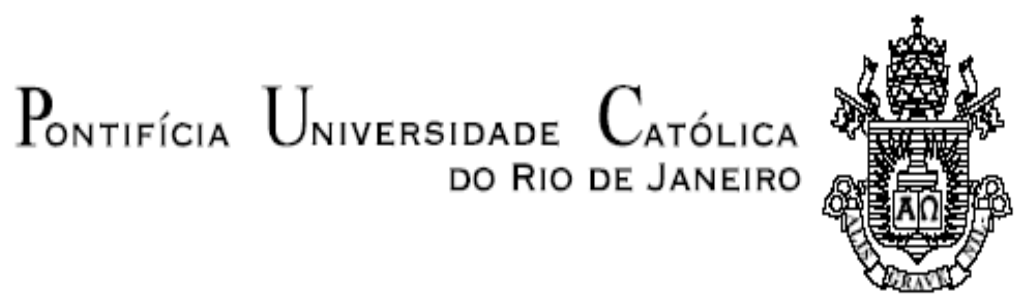

Vitória Manzani Mainieri Piedade

\title{
A revitalização de conjuntos arquitetônicos obsoletos: estudo de casos na cidade de São Paulo
}

Dissertação de Mestrado

Dissertação apresentada como requisito parcial para obtenção do grau de Mestre pelo Programa de PósGraduação em Engenharia Urbana e Ambiental (opção Profissional) do Departamento de Engenharia Civil da PUC - Rio.

Orientador: Prof. Celso Romanel Co-orientador: Prof. Emil de Souza Sánchez Filho

Rio de Janeiro Novembro de 2013 


\section{Pontifícia Universidade Católica \\ DO RIO DE JANEIRO}

\section{Vitória Manzani Mainieri Piedade}

\section{A revitalização de conjuntos arquitetônicos obsoletos: estudo de casos na cidade de São Paulo}

Dissertação apresentada como requisito parcial para obtenção do grau de Mestre pelo Programa de PósGraduação em Engenharia Urbana e Ambiental (opção Profissional) do Departamento de Engenharia Civil da PUC - Rio. Aprovada pela comissão examinadora abaixo assinada.

Prof. Celso Romanel

Presidente / Orientador

Departamento de Engenharia Civil - PUC-Rio

Prof. Emil de Souza Sánchez Filho

Co-orientador

Departamento de Engenharia Civil - UFF

Prof $^{\mathrm{a}}$ Marta de Souza Lima Velasco Departamento de Engenharia Civil - PUC-Rio

Prof ${ }^{\mathrm{a}}$ Maria Teresa Gomes Barbosa Departamento de Engenharia Civil - UFJF

Prof. Fábio Oliveira Bitencourt Filho Faculdade de Arquitetura e Urbanismo Programa de Pós-graduação em Arquitetura - UFRJ

Prof. José Eugenio Leal Vice-Decano de Pós-graduação Centro Técnico Científico - PUC-Rio

Rio de Janeiro, 25 de Novembro de 2013. 
Todos os direitos reservados. É proibida a reprodução total ou parcial do trabalho sem autorização do autor, do orientador e da universidade.

\section{Vitória Manzani Mainieri Piedade}

Graduou-se em Arquitetura e Urbanismo pela Faculdade de Arquitetura e Urbanismo da UFRJ em 1985. Desde então, atua na Administração Pública Federal, na área de projetos e licitações públicas.

Ficha Catalográfica

Piedade, Vitória Manzani Mainieri

A revitalização de conjuntos arquitetônicos obsoletos: estudo de casos na cidade de São Paulo / Vitória Manzani Mainieri Piedade ; orientador: Celso Romanel ; co-orientador: Emil de Souza Sánchez Filho. - 2013.

123 f. : il. (color.) ; $30 \mathrm{~cm}$

Dissertação (mestrado)-Pontifícia Universidade Católica do Rio de Janeiro, Departamento de Engenharia Civil, Programa de Pós-Graduação em Engenharia Urbana e Ambiental, 2013. Inclui bibliografia

1. Engenharia civil - Teses. 2. Edifícios industriais. 3. Arquitetura fabril. 4. Centros urbanos. 5. Memória coletiva. 6. Revitalização. 7. Sustentabilidade. I. Romanel, Celso. II. Sánchez Filho, Emil de Souza. III. Pontifícia Universidade Católica do Rio de Janeiro. Departamento de Engenharia Civil. IV. Título.

CDD: 624 
Para Jaques e Rômulo (in memoriam), pelo exemplo do amor pela vida e Ramon, por confiar sempre. 


\section{Resumo}

Piedade, Vitória Manzani Mainieri. Romanel, Celso (Orientador). Filho, Emil de Souza Sánchez (Co-orientador). Revitalização de conjuntos arquitetônicos obsoletos: estudo de casos na cidade de São Paulo. Rio de Janeiro, 2013. 123 p. Dissertação de Mestrado - Departamento de Engenharia Civil, Pontifícia Universidade Católica do Rio de Janeiro.

Os edifícios industriais representam parte da herança cultural da população de uma cidade, muitas vezes negligenciada. Na maioria dos casos ocupam uma importante parcela na definição da identidade do local e de seus habitantes.

Esta dissertação trata da reutilização de conjuntos fabris e industriais localizados em áreas periféricas de grandes cidades, que se tornaram obsoletos devido à reconversão econômica ocorrida após a era de apogeu das atividades industriais, e avalia de que maneira sua revitalização pode contribuir para a expansão territorial dos centros urbanos de maneira sustentável.

A temática da reutilização adquire relevância pela recorrente situação de abandono que afeta as estruturas de antigas instalações industriais nas cidades contemporâneas.

Os estabelecimentos industriais passaram a ser considerados como bens culturais dignos de preservação somente a partir de 1950, especificamente na Inglaterra, quando foram demolidos importantes testemunhos.

A abordagem busca valorizar a preservação da memória individual e coletiva relacionada à arqueologia industrial.

O estudo faz uma breve referência a alguns exemplos onde a revitalização se apresentou como uma solução ideal para possibilitar a manutenção do patrimônio edificado e simultaneamente devolver à população espaços sub utilizados, evitando o processo previsível de deterioração, sucateamento e ocupação clandestina.

A atribuição de um novo uso compatível com as características das estruturas remanescentes e condizente com o valor cultural atribuído a essas preexistências torna-se um valioso instrumento de preservação, justamente por reverter um ciclo de decadência e obsolescência a que estão submetidos esses 
conjuntos arquitetônicos representativos do início da industrialização no Brasil.

Dentre as disposições trazidas na Carta de Nizhny Tagil, sobre as condições de adaptação e novos usos dos prédios fabris destaca-se:

5. v Adaptar e continuar a utilizar edifícios industriais evita o desperdício de energia e contribui para o desenvolvimento sustentado. O patrimônio industrial pode desempenhar um papel importante na regeneração econômica das regiões deprimidas ou em declínio. A continuidade que esta reutilização implica pode proporcionar um equilíbrio psicológico às comunidades confrontadas com a perda súbita de uma fonte de trabalho de muitos anos. $\left(\mathrm{TICCIH}^{1}, 2003\right)$

A partir do documento é possível concluir que manter um edifício em uso equivale a um mecanismo favorável à sua conservação, uma vez que exige manutenção periódica do bem em questão. Por outro lado, o abandono favorece a deterioração e perda dos importantes testemunhos de interesse ao patrimônio cultural.

Busca-se também a valorização imobiliária das edificações enquadradas no universo da pesquisa, uma vez que sua localização em áreas integradas aos centros urbanos e, portanto, já servidas por uma infraestrutura de serviços públicos, revelam tendências à especulação imobiliária, favorecendo sua descaracterização.

No universo social, são apresentados argumentos favoráveis à preservação dos espaços industriais como sustentáculo da memória individual dos empregados, na maioria dos casos imigrantes, seus familiares e descendentes, habitantes contemporâneos das cidades, potenciais usuários dos espaços representativos de sua história. Com essa conduta torna-se possível valorizar também a memória coletiva da população que vivencia, com o ressurgimento da função daqueles espaços, uma possibilidade de transmitir a história da sua cidade para outras gerações.

A cidade de São Paulo pode ser considerada como um berço da imigração no Brasil tendo, portanto, vivenciado o surgimento e desenvolvimento de núcleos urbanos em torno das fábricas lá instaladas. Tal realidade trouxe como consequência o rápido desenvolvimento na infraestrutura urbana de serviços públicos e grandes avanços na economia da cidade. Nesse contexto de investimentos em prol do crescimento econômico surgiram na paisagem grandes edifícios e conjuntos de edificações fabris. Para comportar os mercados públicos, indústrias de serviços públicos (energia, esgoto e drenagem e iluminação pública), 
bem como estações ferroviárias e seus galpões foram construídos prédios imponentes utilizando, muitas vezes, materiais importados como o ferro e vidro.

A construção de alguns desses exemplares representa um marco na arquitetura da cidade, já que foram concebidos a partir de projetos originados ou com grande influência das escolas mais renomadas do mundo, por exemplo a Bélgica (Francisco de Paula Ramos de Azevedo, 1928 - Mercado Municipal de São Paulo), a Itália (Giovanni Battista Bianchi, em 1936 - Cotonifício Rodolfo Crespi) e França (Paul Pedraurrieux, em 1912 - 1916 - Vila Operária Maria Zélia).

Paralelamente, o enfoque técnico da pesquisa apresenta registros numéricos do consumo de recursos naturais, materiais e insumos relacionados à produção e aplicação de elementos construtivos encontrados nos casos estudados, para permitir a avaliação da economia gerada por meio do reaproveitamento dos mesmos, nos processos de revitalização.

Com o objetivo de ilustrar a pesquisa e avaliar dados técnicos de importantes obras de revitalização na cidade de São Paulo foram escolhidas as obras do Matadouro Municipal de São Paulo, que atualmente abriga a sede da Cinemateca Brasileira e suas instalações de apoio, bem como espaços para exposições e o conjunto de edificações da Usina de Gás e Carvão da Cidade de São Paulo, cujas obras de revitalização em andamento visam sediar o Museu da História da Cidade de São Paulo.

Esta pesquisa considerou que parte dos elementos construtivos presentes nos exemplares estudados ainda se apresentam em fase de aproveitamento de sua vida útil, justificando assim os investimentos em sua manutenção por ocasião de revitalização ou reconversão daqueles espaços que os abrigam.

Foram pesquisados os processos de fabricação de insumos componentes de certos elementos construtivos presentes naqueles edifícios industriais como, por exemplo, os tijolos cerâmicos, as estruturas de ferro e de concreto. Buscando comprovar a importância da preservação daqueles recursos, foram apresentados os dados de consumo de matérias primas e combustíveis envolvidos nos processos.

$\mathrm{Na}$ mesma direção apontada pelas iniciativas de reaproveitamento, os resultados investigatórios mostram a possibilidade de redução nas emissões de gases do efeito estufa e nos gastos energéticos, na medida em que é reduzido o montante de produtos industrializados nas construções revitalizadas. 
Ao final da análise e interpretação dos dados técnicos das obras é apresentada uma tabela que visa o lançamento da quantidade estimada daqueles elementos com potencial de reaproveitamento e a correlação da quantidade de matéria prima preservada, bem como das emissões atmosféricas poupadas. Desse modo torna-se mais clara e objetiva a percepção das vantagens econômicas e ambientais resultantes do reaproveitamento, subsidiando as decisões a serem adotadas nos processos de revitalização.

As pesquisas realizadas resultam na conclusão de que a conservação de importantes sítios industriais, inseridos no espaço urbano de grandes metrópoles, surge como uma opção para ocupação de espaços subutilizados, privilegiando a manutenção da memória coletiva, o reaproveitamento das estruturas prediais e destacando a economia de recursos e energia intrínsecos ao processo.

\section{Palavras chave}

Edifícios industriais; arquitetura fabril; centros urbanos; memória coletiva; revitalização; sustentabilidade. 


\section{Abstract}

Piedade, Vitória Manzani Mainieri; Romanel, Celso (Advisor); Filho, Emil de Souza Sánchez (Co-advisor). Revitalization of obsolete arquitetonic sites: case studies in the city of São Paulo. Rio de Janeiro, 2013. 123 p. MSc Dissertation - Departamento de Engenharia Civil, Pontifícia Universidade Católica do Rio de Janeiro.

The industrial buildings represent part of the population's cultural heritage of a city's, often neglected. In many cases they occupy an important part in definition of the place identity and its inhabitants.

This research deals with the reutilization of industrial and manufacturing buildings located in peripheral areas of large cities, which became obsolete due to the economic restructuring that occurred after the heyday era of industrial activities, and assesses how their revitalization can contribute to territorial urban centers expansion in a sustainable approach.

The theme of reuse becomes relevant by the recurrent abandonment situation that affects the old industrial sites structures in contemporary cities.

Industrial establishments came to be regarded as cultural properties worthy of preserving only from 1950, specifically in England, when key buildings were demolished.

The approach seeks to value the individual and collective social memory preservation related to industrial archeology.

The study makes a brief reference to some examples where revitalization is presented as an ideal solution to enable the maintenance of the built heritage and simultaneously restore underutilized spaces back to the population, avoiding the predictable process of deterioration, obsolescence and illegal occupation.

The assignment of a new use, at the same time compatible with the characteristics of the remaining structures and consistent with the cultural value attached to those preexistence, becomes a valuable preservation tool, specially because it reverses the declining and obsolescence cycle that afflicts these architectural ensembles which represent the beginning of industrialization in Brazil. 
Among the provisions brought in Nizhny Tagil letter, on the conditions of adaptation and new uses of industrial buildings stands out:

5. $\mathrm{v}$ To adapt and continue to use industrial buildings avoids wasting energy and contributes to sustainable development. The industrial heritage can play an important role in the economic regeneration of depressed or declining areas. The continuity that reutilization implies can provide a psychological balance to communities faced with the sudden loss of a working source of many years. $\left(\mathrm{TICCIH}^{2}, 2003\right)$

From the document contents we conclude that maintaining a building in use is equivalent to a favorable conservation mechanism, since it requires periodic maintenance of the property in question. On the other hand, the abandonment foments deterioration and loss of important cultural heritage interest remains.

The aim is also the real estate valuation of buildings framed in the survey, since their location in urban centers' integrated areas and, therefore, already served by public infrastructure services, reveals trends for real estate speculation, favoring its mischaracterization.

In the social universe, favorable arguments are presented to the preservation of industrial spaces as individual supporter of the employees' memories, majority composed of immigrants, their families and descendants, as contemporary city dwellers, potential users of representative spaces in its history. With this approach it is also possible to enhance the collective memory of the population that will experience, by the resurgence of those areas' functionality, the possibility of transmitting their city history to other generations.

The city of São Paulo can be considered as a cradle of immigration in Brazil, having experienced the emergence and development of urban areas around the factories installed there. Such reality has had an effect on the rapid development of urban infrastructure utilities and major advances in the city's economy. In this context of investments to promote economic growth large buildings and sets of factory buildings emerged in landscape. To accommodate the public markets, public services (energy, sewage and drainage and public lighting) industries as well as railway stations and its sheds, imposing buildings were constructed using most of the time imported materials, such as iron and glass.

The construction of some of these examples represents a milestone in the

The International Comittee for the Conservation of the Industrial Heritage. 
city's architecture, as they were designed from projects originate from or with major influence of the most prestigious schools in the world, for example Belgium (Francisco de Paula Ramos de Azevedo, 1928 - Municipal Market of São Paulo), Italy (Giovanni Battista Bianchi in 1936 - Cotonifício Rodolfo Crespi) and France (Paul Pedraurrieux in 1912-1916 - Vila Maria Zélia).

In parallel, the technical focus of the research presents numerical records of the natural resources consumption, materials and supplies related to the production and application of constructive elements found in the cases studied, to allow assessment of the savings generated through their reuse, in the process of revitalization.

In order to illustrate the research and evaluate technical data of important revitalization examples in São Paulo city, The Municipal Slaughterhouse works of São Paulo, which currently houses the headquarters of the Cinemateca Brasileira and its supporting facilities, as well as spaces for exhibitions, and the group of buildings of the São Paulo Gas and Coal Plant, whose revitalization works, yet in progress, were chosen to host the Historical Museum of the City of São Paulo.

This research has considered that part of the building elements present in the studied samples are still under useful life, thereby justifying investments for their maintenance during the regeneration or conversion of those spaces that house.

Manufacturing processes of the components of certain building elements present in those industrial buildings were researched, for example, ceramic bricks, iron and concrete structures. Seeking to prove the importance of preserving those resources, data consumption of raw materials and fuels involved in the process were presented.

In the same direction of the reuse initiatives, investigative results show the possibility of reduction in emissions of greenhouse gases and energy costs, in the same proportion as the processed products in revitalized buildings is also reduced.

At the end of the analysis and interpretation of technical data from the building works, this research presents a table to launch the estimated amount of those elements with potential for reuse and the correlation of the amount of raw material preserved and spared from air emissions. Thus the perception of the economic and environmental benefits resulting from reuse becomes clearer and more objective, assisting the decisions to be taken in the process of revitalization. 
The researches carried out resulting in the conclusion that the maintenance and conservation of important industrial sites inserted in the urban area of big cities, emerges as an option for occupancy of underutilized spaces, favoring the maintenance of collective memory, the reuse of building structures and highlighting the economy resources and energy inherent to the process.

\section{Keywords}

Industrial buildings; factory architecture; urban centers; collective memory; revitalization; sustainability. 


\section{Sumário}

\section{Introdução}

$\begin{array}{ll}1.1 \text { Notas iniciais } & 20\end{array}$

1.2 O problema 22

1.3 Justificativa 24

1.4 Objetivos 28

1.4.1 Objetivo geral 28

1.4.2 Objetivos específicos $\quad 29$

1.5 Metodologia de pesquisa 29

1.6 Delimitação do estudo 31

1.7 Definições dos termos 32

1.8 Organização do trabalho 33

\section{A sustentabilidade metropolitana}

2.1 Notas iniciais

2.2 A industrialização como processo de urbanização e desenvolvimento das cidades

2.3 Problemas relacionados à reconversão econômica e esvaziamento dos complexos industriais

2.4 O patrimônio como sustentáculo da memória social

2.5 A preservação dos edifícios e a redução dos impactos ambientais

3 A identidade do patrimônio industrial edificado

3.1. Tipologia arquitetônica dos edifícios fabris e industriais

3.2 Os materiais do mundo fabril

3.2.1 Aspectos do processo de fabricação de tijolos cerâmicos

3.2.2 Características dos elementos metálicos estruturais e de cobertura

3.2.3 Estruturas de concreto armado, composição e processos industriais

\section{Estudo de casos}

4.1 Considerações iniciais 
localizado no bairro da Vila Mariana

4.3 Casa das Retortas - conjunto de edificações da Usina de Gás e Carvão da Cidade de São Paulo

\title{
5 Análise de resultados
}

5.1 Coleta de dados 97

5.1.1 Estudo de caso 1 - Matadouro Municipal 97

5.1.2 Estudo de caso 2 - Complexo da Casa das Retortas 99

5.2 Interpretações 101

6 Conclusões e sugestões para trabalhos futuros 105

$\begin{array}{ll}\text { Referências } & 108\end{array}$

\begin{abstract}
Anexos
1 - Desenho 0.01 - Cinemateca Brasileira - Salão de eventos

- Projeto básico - Planta pavimento térreo

2 - Desenho 0.02 - Cinemateca Brasileira - Salão de eventos

- Projeto básico - Cobertura e cortes

3 - Desenho 01/04 - Projeto básico de restauro - Edifício Casa das Retortas - Pavimento térreo e subsolo

4 - Desenho 02/04 - Projeto básico de restauro - Edifício Casa das Retortas - Planta do mezanino e cobertura

5 - Desenho 03/04 - Projeto básico de restauro - Edifício Casa das Retortas - Fachada leste e corte AA

6 - Desenho 04/04 - Projeto básico de restauro - Edifício Casa das Retortas - Situação, cortes transversais e fachadas norte e sul.
\end{abstract}




\section{Lista de siglas}

ABM - Associação Brasileira de Metalurgia e Materiais

BIRD - Banco Internacional para a Reconstrução e Desenvolvimento

CBCS - Conselho Brasileiro de Construção Sustentável

CONDEPHAAT - Conselho de Defesa do Patrimônio Histórico, Arqueológico, Artístico e Turístico do Estado de São Paulo

CONPRESP - Conselho Municipal de Preservação do Patrimônio Histórico, Cultural e Ambiental da Cidade de São Paulo

DNPM - Departamento Nacional de Produção Mineral

EPE - Empresa de Pesquisa Energética

FBDS - Fundação Brasileira para o Desenvolvimento Sustentável

FIB - Fédération Internationale du Béton (International Federation for Structural Concrete

MME - Ministério de Minas e Energia

RDC - Resíduos de construção e demolição

SEBRAE/ESPM - Serviço de Apoio às Micro e Pequenas Empresas/Escola Superior de Propaganda e Marketing

SEMAHR - Secretaria de Meio Ambiente e Recursos Hídricos

SNIC - Sindicato Nacional da Indústria de Cimento

TICCIH - The International Committee for the Conservation of the Industrial Heritage

UNEP - United Nations Environment Programme 


\section{Lista de figuras}

Figura 1.1 - Bairro de Cascatinha, Petrópolis, Rio de Janeiro - 1906.

Figura 1.2 - Fachada principal da Companhia Petropolitana de Tecidos, Petrópolis, Rio de Janeiro

Figura 1.3 - Esquema da pesquisa desenvolvida

Figura 1.4 - Imagem panorâmica da Fábrica de tecidos Bangu. Século XIX

Figura 1.5 - A inauguração da Vila Maria Zélia, em 1917

Figura 1.6 - Equilíbrio entre os três pilares da sustentabilidade

Figura 3.7 - Localização dos municípios de Tatuí, Sorocaba, Jundiaí e São Paulo

Figura 3.8 - Vista geral da fábrica, com o prédio ainda existente do cotonifício ao fundo [1922 - 1924]

Figura 3.9 - A fachada do antigo Cotonifício Crespi

Figura 3.10 - Localização da Subprefeitura da Mooca e os bairros que a compõem

Figura 3.11 - Extração de barro em jazidas

Figura 3.12 - Degradação ambiental ocasionada pela extração ilegal de mineral

Figura 3.13 - Fluxograma das operações unitárias da produção de matéria prima e preparação de massa cerâmica

Figura 3.14 - Esquema das fases do ciclo de vida dos principais produtos cerâmicos

Figura 3.15 - Fluxo simplificado da produção de aço

Figura 3.16 - Emissão específica de $\mathrm{CO}_{2}$ na indústria siderúrgica

Figura 3.17 - Extração de calcário para indústria de cimento

Figura 3.18 - Poeira produzida pela extração de calcário na região, cobrindo a vegetação

Figura 3.19 - Produção de cimento pelo processo úmido

Figura 3.20 - Indústria de cimento

Figura 4.21 - Matadouro Municipal em funcionamento. Início do século XX

Figura 4.22 - Matadouro Municipal de São Paulo. Visão geral dos galpões restaurados

Figura 4.23 - Implantação dos prédios da Cinemateca 
Figura 4.24 - Utilização de caixilhos em aço na cor preta

Figura 4.25 - Permeabilidade visual garantida pela substituição de portões de ferro originais por vidro

Figura 4.26 - Passarela de interligação entre os prédios sob cobertura de vidro

Figura 4.27 - Visão geral dos galpões restaurados, cuja conexão se faz por meio de passarelas cobertas com vidro, atirantadas às alvenarias externas

Figura 4.28 - Elementos construtivos e intervenções anteriores preservadas, em favor da memória e do reaproveitamento de materiais

Figura 4.29 - Adequação dos elementos originais às tecnologias contemporâneas

Figura 4.30 - Casa das Retortas - Fachada voltada para a Rua Domitila $\quad 69$

Figura 4.31 - Casa das Retortas - Interior - Baterias 3 e 4 (1915) 90

Figura 4.32 - Casa das Retortas - Bateria de fornos 91

Figura 4.33 - Casa das Retortas - Descarga de um vagão de carvão e o sistema elevatório que removia do fosso para o depósito

Figura 4.34 - Casa das Retortas - Vista do conjunto com frente para a Rua do Gasômetro

Figura 4.35 - Identificação das construções do complexo das Retortas, anterior ao projeto de revitalização

Figura 4.36 - Projeto do Museu da História de São Paulo - Imagem digital

- Vista do conjunto

Figura 5.37 - Pilar e viga metálicos preservados

Figura 5.38 - Integração de elementos estruturais originais e contemporâneos

Foto 6.39 - Mercado Municipal de São Paulo. Bairro da Sé. Fachada da rua da Cantareira

Foto 6.40 - Interior. Vista do mezanino 


\section{Lista de tabelas e gráficos}

Tabela 3.1 - Consumo energético e emissões de $\mathrm{CO}_{2}$ na mineração da argila

Tabela 3.2 - Consumo de insumos e emissões na produção industrial de $1 \mathrm{~m}^{2}$ de parede de tijolos de barro

Tabela 3.3 - Consumo de lenha e produção de tijolos em oito olarias do

Distrito Federal

Tabela 3.4 - Consumo energético na indústria cerâmica

Tabela 3.5 - Principais insumos e produtos energia e materiais na produção de aço

Tabela 3.6 - Consumo de matérias primas na fabricação de aço

Tabela 3.7 - Estimativa de emissões de $\mathrm{CO}_{2}$ em 2007 (em mil t $\mathrm{CO}_{2}$ )

Tabela 3.8 - Elementos químicos mais abundantes na crosta terrestre.

Tabela 3.9 - Consumo energético na fabricação de cimento

Tabela 3.10 - Lista das questões mais importantes relacionadas à sustentabilidade.

Tabela 3.11 - Emissões mais significativas na fabricação de cimento

Tabela 4.12 - Elementos construtivos preservados com a revitalização do Matadouro Municipal

Tabela 5.13 - Elementos construtivos preservados com a revitalização do complexo das Retortas

Tabela 5.14 - Consumos nos processos de fabricação e aplicação na construção civil.

Tabela 5.15 - Emissões nos processos de extração de matéria prima e fabricação de produtos

Tabela 5.16 - Ganhos verificados nas obras estudadas

Tabela 5.17 - Cadastro de elementos preservados 
São três maneiras de utilizar o passado para viver. Elas correspondem a três tipos de homens: o criador utiliza o passado como exemplo ou modelo (monumental), o conservador enraíza sua vida e seus valores no passado (antiquário) e o reformador utiliza o passado para negálo e assim ultrapassá-lo (crítico). Elas podem ser tanto úteis quanto nocivas à vida, dependendo de sua complementaridade e de sua subordinação à vida.

(NIETZSCHE, 1874 apud CAMUS et al, 2011, p. 19, grifo nosso). 